臨床報告＼cjkstart異常感覚と気管支喘息に駆瘀血剂が 有効であった 1 例

\author{
小泉久仁弥 花輪 壽彦 \\ 石野 尚吾 大塚 恭男
}

\title{
A Case of Dysesthesia and Bronchial Asthma Treated with Ku-oketu-zai Effectively
}

\author{
Kuniya KOIZUMI Toshihiko HANAWA \\ Syogo ISHINO Yasuo OTUKA
}

M.D., Department of Kampo medicine, Oriental Medicine Research Center of The Kitasato Institute, 5-9-1, Sirogane, Minato-ku, Tokyo 108, Japan

Summary 28 years-old male patient has felt dysesthesia as swelling of forehead, numbness of cheeks and pain of eyes. Dysesthesia has developed gradually.

"Fuku-myaku" means the pulse difficult to be palpable. This characteristic pulse and Oketsu symptoms suggested the indications of Tokaku-joki-to and Tokaku-joki-to-go-Daio-botampi-to. As we had found "Fuku-myaku" and oketsu syndrome in this patient, we treated with these kampo medicine according to "Sho" diagnosed by Kampo. The dysesthesia in the patient has been gradually disappeared. At the same time, attacks of asthma which had appeared after discontinuation of Saiboku-to administration have been also disappeared. It is easy to make a mistake that "Fuku-myaku" is for pulse of hypo-functioning condition. But we understand that "Fuku-myaku" is not always for pulse of hypo-functioning condition, but for hyper-functioning condition.

Key words: dysesthesia, bronchial asthma, Tokaku-joki-to, Tokaku-joki-to-go-Daio-botampi-to, fuku-myaku

Nihon Toyo Igaku Zasshi (Japanese Journal of Orienta! Medicine), 45, 575-577, 1995 (accepted Jan 21, 1994)

\section{はじめに}

異常感覚に駆瘀血剂を使用した例1 ${ }^{13)}$ や気管支 喘息に駆瘀血剂が奏効した症例報告(4はなされて いるが，今回我々は，異常感覚と気管支喘息を㐼 せもつ症例を経験し，駆族血剂により異常感覚だ
けではなく気管支喘息も改善した症例を経験し， その脈証について文献的考察を加えたので報告す る。

\section{症 例}

症 例: 28 歳外性:

医, 北里研究所東洋医学総合研究所漢方診㞠部, 東京, $\bar{\top} 108$ 港区白金5-9-1 


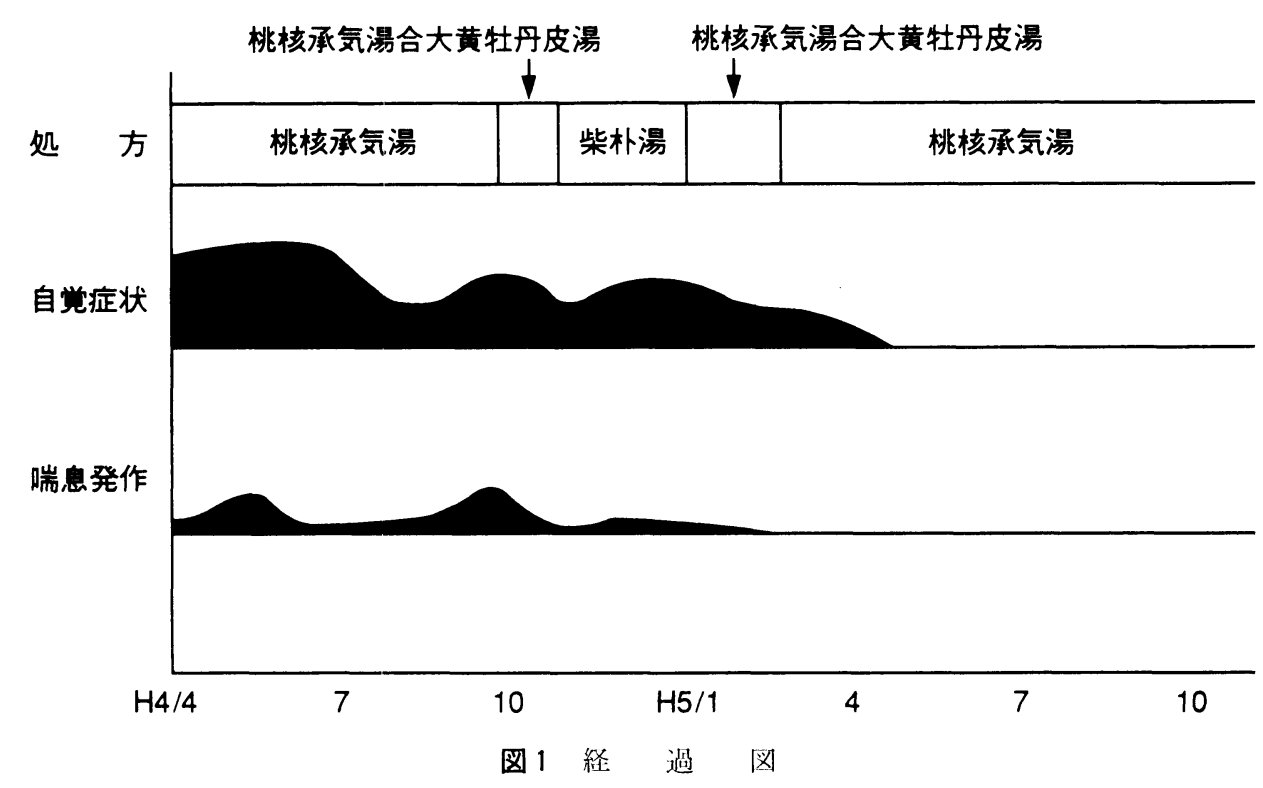

主 訴：「前額部が膨らさ」という珙常感覚。 家旅歴：母親が癌で死亡（詳細不明）

既往歴：6 歳 急性虫垂炎。6 歳より気管支喘 息があり，2 年前より近医でッムラ柴朴湯エキス を処方されている。

現病歴：平成 3 年春頃から，会議など緊㲀する ときに，前額部が膨らも感覚，煩部のしびれ，目 の痛みが出るようになった。また，運動時に動悸 がするため, K病院にてホルタ一心電図の検査を したが，異常はなかった。これらの症状が悪化 し, 発生頻度が高くなったため, 漢力治療を希望 して当診療部受診。その他の症状には頭重, 後頸 蔀のこり，肩こり，ほてり，のぼせがある。食欲 は普通で，睡眠はよい。大便は 1 日に 2 行で普通 便である。 初㡎。

身体所見：身長 $174 \mathrm{~cm}$, 体重 $68 \mathrm{~kg}$, 血玨124/ $70 \mathrm{mmHg}$, 知覚障害なし, 運動障害なし, 視力 正常，眼臉結膜貧血なし，眼球結膜黃㾝なし，胸 部聴打診上晎常なし。

東洋医学的所見：顔色は埥，画色は淡で迷痕が あるが舌苔はない, 脈は伏数, 腹力は実, 両側の

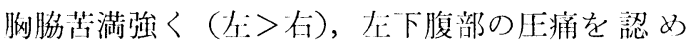
た。

処 方: 桃核承気湯（桃仁5.0 桂枝4.0 芒硝 0.5 大黄 0.5 甘草 1.5 )
経 過（図 1)：2週後にツムラ柴朴湯エキス を中止したところ軽い喘息発作が 3 回起こった がそそのまま様子をみていたところ改善した。

6 週後には会議が長引くと䫓が膨らさ感じがで る。頻尿となった。

3 力月後には会議が長いときや車を運転してい るときは悪いが，少しずつ全ての症状が軽くなっ てきている。欠伸が頻繁にでる。ツムラ甘麦大慗 湯エキス $2.5 \mathrm{~g}$ を欠伸時の頓服として併用。

5 力月後には, 先月は調子がよかったという。 今月になって多忙であったところ，腹部のしびれ で始まり，次第に手足がしびれ，ロがまわらなく なるといら症状が出た。欠伸は頓服の服用で消失 し，その後出ていない。

下腹部の王痛が左右両側に出現したため，処才j を桃核承気湯合大黄牡丹皮湯（桃价5.0 桂枝4.0 芒硝 0.5 大黄 0.5 甘草 1.5 牡丹皮 4.0 瓜子 6.0）に変更した。

6 力月後に, 先月末より 2 甘に 1 以程度の㟨息 発作が起こり，吸入をしている。

下腹部の圧痛が不明膫となり, 胸脇苦満などよ り処方を柴朴湯に変更した。

8 力月後には, 歩行時に視力が落ち, 在耳が聞 こえなくなり，手足のしびれ，話が出来なくなり， 夢心地になることが 1 度あった。1時間休んだと 
ころ落ち着いた。喘息は朝疢が出る程度で発作は ない。

﨩側下腹部の圧痛より, 処方を桃核承気湯合大 黄牡丹皮湯に変更した。

10力月後には, 喘息発作が起きなくなった。会 議中に, のぼせ，手が冷たくなるなどの症状が出 るが，以前程ひどくはない。

下腹部の圧痛が左のみとなったため処方を桃核 承気湯に変更した。

12力月後は，調子良い。喘息も起きない。

13力月後は，体調良い。

\section{考 案}

この症例は, 腹証で胸脇苦満と瘀向があり柴胡 剂にするか桃核承気湯にするかまた，その合方に するか迷った症例であった。前医よりの柴朴湯の 処方, 伏脈といった特徵的な脈, 晹本求滇の「病 血のある患者には，必ず胸脇苦満が合併してい $\left.る^{5)}\right\rfloor と い ら$ 主張, 皇漢醫學の伏脈の解説の ${ }^{6}$ 「余曰ク此脈㧩アルニ際シ徒二『カンフル』注射 ヨ事トシ下剤习顧ミザルノ醫家稀ナラズ猛省スベ シ。」な゙より，伏脈が下法の適応する脈であり， また胸脇苦満は客証であると考光，便秘はなから たが下腹部の圧痛と考台合わせ桃核承気湯を処方 した。服薬後，脈が次第に触知しやすくなるとと もに症状が改善し始めたところが特徵的であっ た。温疫論の體厥 ${ }^{7}$ に「今已脉微欲絶。按之如 無。比之無力更甚。(中略) 表裏互較。此陽證之 最者。下證悉具。但嫌下之晚耳。蓋因内熱之極。

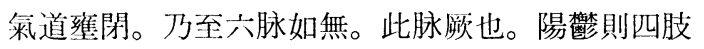
顾逆。」とあり, 皇漢醫學に ${ }^{6)} \Gamma$ 然レドモ此レ必ズ 暴病, 暴逆ノモノニ乃チ之レ有リ其氣习調フレバ 而チ脈自ラ復ス。」とある。下寸ことにより榃がと
れ気が調えば脈は改善することが書かれており， 本症例も例外ではなかった。また, 腹証では下腹 部の圧痛が著明であり，これが大黄を含めた生薬 の駆瘀血作用により軽減したことも，この症例が 改善したもら一つの理由と考学る。

伏脈は, 「沈脈の程度の強いもので, 深く圧し て, やっと触れる脈8 。」であるから陰証で虚証の 脈々間違えやすい。このことは, 皇漢醫學に9 桃 核承気湯の適応に附子理中湯を処方した例が挙げ られていることからもらかがえる。伏脈のような 一見すると陰証で虚証にみえる脈に, 下法の適応 があることに注意が必要である。

この論文の内容は, 日本東洋医学会第50回関東甲信 越支部会において報告した症例である。

\section{文 献}

1）大塚敬節：大塚敬節著作集第 3 卷, p. 163 , 春陽 堂書店, 1980, 東京

2 ）大塚敬節 : 大塚敬節著作集第 3 卷, p. 201, 春陽 堂書店, 1980, 東京

3 ）大塚敬節 : 大塚敬節著作集第 4 卷, pp.129-130, 春陽堂書店, 1980, 東京

4）松浦達雄, 岡 孝和：父管支浉息汇対する桃核承 父湯の使用経験, 第41回日本東洋医学会学術総会 講演要旨集, p.17, 日本東洋医学会, 1990, 福岡

5 ）大塚敬節 : 大塚敬節著作集第 1 巻, pp.122-123, 春陽堂書店, 1980, 東京

6 ) 湯本求眞 : 皇漢醫學第壹卷, pp. 23-24, 燎原, 1976, 東京

7 ) 呉 有性: 温疫論, pp.246-251, 壮版科学総合研 究所, 1980, 東京

8 ）大塚敬節, 矢数道明, 清水藤太郎: 漢少 診療医 典, p.34, 南山堂, 1986, 東京

9 ) 湯本求覓: 皇漢醫學第參巻, pp.180-189, 燎原, 1976, 東京

要旨 症例は28歳男性。6 歳より気管支喘息があった。27歳侍に, 前額部が膨らむ感覚, 煩 部のしびれ，目の痛みなどの異常感覚が出現。次第に悪化してきた。伏といった特徵的な脈証: と瘀血の徴候より桃核承気湯，桃核承気湯合大黄牡丹皮湯を証に応じて使い分け，次第に異常 感覚が消失。柴朴湯エキス中止後に出現していた喘息発作も，次第に出現しなくなった。「伏」 といった一見虚証と間違いやすい脈の中に実証の脈があることを再認識した。

キーワード：異常感覚, 気管支喘息, 桃核承気湯, 桃核承気湯合大黄牡丹皮湯, 伏脈 